\title{
The pedagogical imperative of values education
}

Terence J Lovat and Neville D Clement

1) Lovat Terence John, Clement Neville David, 'The pedagogical imperative of values education', Journal of Beliefs \& Values, 29 273-285 (2008) 


\section{The pedagogical imperative of values education}

\section{Abstract}

Recent research has exposed the potential of quality teaching to exercise a positive influence on student achievement. Extending beyond surface and factual learning, quality teaching has posited conceptions of 'intellectual depth', ‘communicative competence' and 'self-reflection' as being central to effective learning. Implicit in these conceptions are values dimensions reflected in notions of positive relationships, the centrality of student welfare, school coherence, ambience and organization. The influences of these on student learning, welfare and progress have been observed across public, private and religious sectors, thus confirming earlier studies of similar phenomena in religious schools. Evidence from the Australian Government's Values Education Good Schools Project (VEGPSP) indicates the benefit to all schools of reflecting on, re-evaluating and rethinking the implications of values education for curricula, classroom management and school ethos in the interests of student wellbeing and progress. This indicates a pedagogical imperative for values education which extends beyond boundaries of personal or systemic interests and ideologies. 


\section{Values in education}

Values education, under its diverse forms of moral, character, citizenship or civics education, as well as service learning and programs designed to address social problems such as sex, drug, alcohol, resiliency education and the like, has been the focus of a worldwide renewed interest and energy in recent times. This interest extends beyond particular personal or systemic beliefs or ideologies, connoting rather a pedagogical imperative. By this, we proffer that, first, it has become an imperative that teachers and schools engage in pedagogical practice designed to enhance competencies necessary for personal wellbeing and social cohesion, and, second, that by its very nature such educational activity constitutes values education by whichever name in order to achieve this end effectively. Furthermore, any perception that values education is germane only to those school systems, such as private and religious schools, where values and character formation is an acknowledged and anticipated part of their educational agenda and practice, ignores the findings of current research that effective learning in any school or learning context is expedited by explicit emphasis on the intrinsic moral nature of quality teaching and schooling (Bryk, 1988; Carr, 2005, 2006; Halliday, 1998; Hansen, 1998; Lovat \& Clement, 2008).

Indeed, all school systems, whether sponsored by public, private or religious constituencies, are actively involved in values education, either explicitly or implicitly, because the entire enterprise of education is intrinsically values-laden and therefore is instrumental in the values formation of its students (e.g. Australian Government Department of Education, Science and Training (AGDEST), 2005; Aspin, 2000; Bryk, 1988; Carbone, 1991; Clement, 2007; Elliott \& Hatton, 1994; Halstead, 1996; Hooper, 2003; Lovat \& Schofield, 2004; Veugelers, 2000; Veugelers \& Vedder, 2003). In other words, the very quality and effectiveness of education itself 
relates directly to the values that impel and are embedded in its ethos (McLaughlin, 2005; Prosser \& Deakin, 1997). Far from being peripheral to the central issues of curriculum and pedagogy, values lie at the core of what constitutes good pedagogy in practice, and this renders any claims of a 'values free' or 'values neutral' approach to education both impractical and implausible (cf. Bryk, 1988). Therefore, values education has a pedagogical imperative independent of personal or systemic ideologies. What emerges from reflection on the history of values education is that, apart from decisions regarding content, its efficacy is linked to the appropriateness of the curricula, the quality of the pedagogical process, the ambience of the teachinglearning relationships and the modelling of those values aspired to be taught (Cunningham, 2005; Lovat \& Clement, 2008). In examining the case for the pedagogical imperative for values education beyond the boundaries of personal and systemic interests and ideologies, this article will: identify the nature of quality teaching; examine its dependence on the values that lie at its core; and, survey data from the Australian Government's Values Education Good Practice Schools Project (VEGPSP) (AGDEST, 2006) in order to demonstrate the pedagogical imperative for values education that extends across personal and systemic interests and ideologies.

\section{The dynamic nature of quality teaching}

Any claim apropos the effectiveness of values education assumes the efficacy of educational intervention in impacting on the development of students. This claim contradicts the view of earlier research that student heritage is the overriding influence on student development and that, consequently, schools are unable to have a significant effect on student learning (Central Advisory Council for Education (UK), 1967; Coleman et al., 1966; Jencks \& et al, 1972; Rutter et al., 1979). Challenge to this perception arose in the latter part of the twentieth century from research findings 
from the neurosciences which gave insight into the learning process, and from observations of schools and school systems, as well as teacher characteristics and practices, that produced enhanced student achievement. This led to a renewed perception about the power of high quality pedagogy, or quality teaching, to impact positively on the development of students across all dimensions of learning (Bryk et al., 1993; Clement, 2007; Lovat, 2007b; Reynolds et al., 1980).

Instrumental in impelling this paradigm shift was the Report of the Carnegie Corporation’s 1994 Task Force on Learning (Carnegie Corporation, 1996) in the USA. The report introduced conceptions of quality teaching that stretched understandings of learning beyond the accepted tasks of cognitive development to include the physical, social, affective and language development of children. Drawing on the implications of the then recent advances in the neurosciences (Bruer, 1999), it concluded that any limitation on student learning owed more to inadequacies in the school and learning environment than to inadequacies in students themselves. In other words, students were endowed with the capacity and potential to learn if ignited by a dynamic learning environment. Indeed, the development of the brain’s capacities was believed to owe more to the educational environment and to students' experiences of learning than to genetic inheritance. Hence, the report directly challenged the conception that a child's developmental trajectory is determined by family heritage and proffered instead that even low performing students, given appropriate pedagogies, could improve their levels of achievement.

The Report also played a part in identifying the range of learning skills that should constitute student achievement. Ideas of learning moved beyond the more familiar focus on cognitive development to embrace the affective domains involving empathy, communication, self-management and reflection. According to the Carnegie 
Report, holistic learning moved beyond the inadequacies of surface learning to engage students at genuine depth whereby their intellectual capacities could unleash affective and conative energies. Hence, differences in school performance were seen to be the result not so much of student heritage as the provision or lack thereof of a supportive and high quality learning environment designed to stimulate the inherent learning capacities of students. Conceptions of student progress and attainment being limited by constrictions of heritage or naturally regulated developmental patterns gave way to the imperative to provide a learning environment that would motivate learning and so provoke the development of innate learning capacities.

Although the Carnegie Report clearly placed the initiative for providing an adequate learning environment in the hands of schools and teachers, it also recognised that this was made possible only by adequate teacher preparation and relevant and ongoing teacher professional development. In addition, Darling-Hammond (1996; 1998; 2000; Darling-Hammond \& Youngs, 2002), a member of the Carnegie taskforce, furnished evidence that correlated student achievement with teacher quality, rather than with a range of other system, teacher and student-related variables. System and teacher-related variables included teacher salary levels, class sizes, ratios of teaching staff to non-teaching staff and the overall spending on education. Studentrelated variables included levels of poverty, language background and minority group status. Of primary importance against all of these variables was the quality of the teacher's subject knowledge, pedagogical knowledge and skill, and the ability to form appropriate relationships with students and their families. This veracity of teacher effect is confirmed in other international studies (Hattie, 2004; Rowe, 2004; Scheerens \& Bosker, 1997; Scheerens et al., 1989). Darling-Hammond (2000) not only emphasised the positive significance of teacher effect, but underlined also the 
cumulative, additive and non-compensatory effects of poor quality (or 'ineffective') teaching (cf. Fallon, 2003; Jordan et al., 1997; Sanders \& Rivers, 1996).

Of further import for the notion of quality teaching was research into the effect of school restructuring on student achievement led by Newmann (1991; Newmann \& Associates, 1996; Newmann et al., 1996; Newmann \& Wehlage, 1995). Newmann’s sole aim was to provide a learning environment where students would engage in learning which went far beyond the simple reproduction of knowledge to encounter learning that impelled ‘intellectual depth’. In order for this to occur at the student level, Newmann and Associates observed the need for a supportive interaction between the different spheres of the classroom, the school and the wider community beyond the school. The learning environment needed to be comprised of a range of pedagogies suitable to the students in question, so providing for students with diverse needs. This organizational structure would be characteristic of the school whose sole purpose was focussed on student achievement and wellbeing (or 'school coherence'). In addition, there was a need for appropriate staff professional development and the intentional creation of trusting supportive relationships, described by Bryk and Schneider (1996; 2002; 2003) as 'relational trust'.

In addition to the studies cited, other substantial evidence-based studies attest to the potential of quality teaching to overturn the effects of disadvantage attributed to gender, school effects, socio-economic status, student heritage, or disability (AltonLee, 2003; Avery, 1999; King et al., 2001; Ladwig \& King, 2003; Reynolds, 1992). Furthermore, it has been shown that quality teaching not only has positive effect on student academic progress, but it contributes also to affective and physical wellbeing (Willms, 2000). In a quality teaching regime, a teacher structures a learning environment optimally according to capacities, prior knowledge and understanding in 
order to advance student learning and capability development. It exacts of teachers creativity and the application of best practice pedagogies in the desire to create a learning environment designed to engage the latent learning capacities and capabilities of students (cf. Clement, 2007). Effective learning occurs where the cognitive, affective and conative energies are engaged in accordance with a learner's capacities and values (Deakin Crick, 2007; Deakin Crick et al., 2004; Deakin Crick et al., 2007). According to Cawsey (2002), learning at its deepest level depends upon a values connection between students and their learning in the making of personal meaning.

\section{Values: the core of quality teaching}

Thus, an examination of the attributes of quality teaching confirms that it is steeped in values, and rests ultimately on effective engagement with and transaction of the values inherent in learning between all stakeholders in the educational enterprise. From the student's perspective, however, it is the immediate experience that has the greatest impact on learning (Wang et al., 1993) and there is none more immediate than the impact of the demeanour of the teacher-student relationship on indepth student engagement in learning. Care and trust are paramount among the teacher qualities that students consistently nominate, as indicated in recent Australian studies (Australian Government House of Representatives Standing Committee on Education and Training, 2002; Brady, 2005; Rowe, 2004; Scanlon, 2004; Slade, 2001). Even when teacher practice is technically questionable, a positive teacherstudent relationship is able to produce superior outcomes (Louden et al., 2005). Furthermore, international scholars like Bryk (1988), Carr (2005; 2006), Halliday (1998), Hansen (1998), Hattie (2004), Noddings (1997) and Van Petegem et al. 
(2008) indicate the crucial importance of a teacher's personal values and the manner in which they are enacted in fostering effective student engagement in learning.

In addition, at the institutional and systemic level, Bryk and Schneider (1996; 2002; 2003) have pointed to the vital need for trust between the various stakeholders, including the principal, teachers, parents and students, in order to facilitate necessary organisational and functional changes essential to support improved student achievement:

Trust relations culminate in important consequences at the organizational level, including more effective decision-making, enhanced social support for innovation, more efficient social control of adults’ work and an expanded moral authority to 'go the extra mile' for the children. Relational trust ... is an organizational property ... its presence (or absence) has important consequences for the functioning of the school and its capacity to engage fundamental change. (2002, p. 22)

At the core of this "relational trust” is the "dynamic interplay among four considerations: respect, competence, personal regard for others, and integrity” (Bryk \& Schneider, 2002, p. 23).

Thus, Bryk and colleagues have identified a moral dimension necessary in the coalescing of form and structure in creating the kind of normative environment capable of having a powerful effect on the academic achievements of students. The researchers observed the constructive influence of positive interpersonal dynamics founded on trust between staff, students and parents. Mutual respect and profound rapport were characteristic of the interaction between students and teachers with the effect being in elevated self-discipline and classroom engagement on the part of students. Teachers were perceived by parents to have a stronger moral commitment to student welfare and learning and parents reciprocated by encouraging and supporting 
the work of the school. The level of trust observed between teachers, students and parents contributed significantly to the promotion and realization of high levels of educational achievement, particularly among disadvantaged youth (Bryk, 1988; Bryk et al., 1993; Bryk \& Schneider, 2002, 2003; c.f. Coleman et al., 1982; Hill et al., 1990; Jencks, 1985; Lee \& Bryk, 1988, 1989).

Furthermore, in a different study of thirteen inner-city high schools in New York and Washington, DC, in socially disadvantaged areas, Hill Foster \& Gendler. (1990) found that, among low income youth, Catholic high schools produced the highest number of graduates and the highest test scores, followed by special public schools. Both were more successful than zoned (comprehensive public) schools. From their observations of the organisational characteristics of these special public schools and Catholic high schools, Hill et al. identified institutional factors that accounted for the positive impact of these 'focus schools': coherent mission; institutional freedom; and organizational capacity and ability to structure themselves for the benefit of student outcomes.

Hence, it is clear that the provision of a trusting and caring environment, together with positive relationships between students and their teachers, impact significantly on student attainment and constitute an especially positive enhancement of the stated impact of quality teaching in reducing the debilitating effects of social disadvantage. It is also clear from the evidence that it is vital that schools have the freedom and capacity to structure themselves for the benefit of student success and wellbeing if these latter are to be optimized. Moreover, the alignment between family and school values offers a stable community in which values are embedded in the ethos of the school and reflected in policy decisions, classroom climate and general student ethos beliefs and attitudes, and points to the significant influence and vital 
importance in values education of the modelling of values and accountability to a community (cf. Leming, 1993; Lickona, 1993). Bryk (1988) maintained that the communal spirit, observed to be the linchpin in the organisation of religious school systems, could be articulated in secular schools through embodiment of values respecting human dignity and social justice, characteristics of sites where relational trust obtains (cf. Lee \& Smith, 1999). Relational trust was shown to be a 'core resource' in school reform and improvement in Chicago elementary schools (Bryk \& Schneider, 2002, 2003). Furthermore, the instance of West Kidlington Public School, UK, which has become an international model of a 'Values-based school', clearly articulates a values-based approach in a secular school system, and thus provides arguably the hardest evidence available anywhere of the transformation in student achievement that can result from a whole school and a whole community coalescing to educate the whole person (Farrer, 2000; Hawkes, 2005, 2007).

In summary, it is evident that values go to the heart of quality teaching as they focus on student capabilities and potentialities, teacher professional practice that has greatest impact and institutional and systemic features attuned best to the facilitation of student achievement and wellbeing. These are the relational qualities of due care, mutual respect, fairness and positive modelling established with the student and, in turn, the network of systemic relational trust that results. Furthermore, it strongly suggests that the practice of quality teaching is questionable and even unattainable in the absence of the values of care and trust because these are the values that, evidence suggests, stand behind the species of relationship between teacher and student that engages students in the kind of learning that optimizes their learning potential. 


\section{Good practice values education for all schools}

The pedagogical imperative for values education across educational systems, irrespective of systemic ideologies, is illustrated in the final report of Stage 1 of the Australian Government's Values Education Good Practice Schools Project (VEGPSP) (AGDEST, 2006), and the more detailed and extended case studies reported in Lovat and Toomey (2007). The VEGPSP was seeded from a Federal Government grant in 2004 of \$29.7 million providing for the development of a National Framework in Values Education (AGDEST, 2005). Central to this framework was the stated nexus between values education and 'best practice pedagogy', and the framework moreover provided the inspirational guidelines for a series of action research projects designed to test the underlying assumptions of the stated nexus. Involving some 316 schools in 51 clusters, across public, private and religious education sectors from every state in Australia in two stages, the VEGPSP was the largest of several projects. Although the values listed in the National Framework for Values Education in Australian Schools (AGDEST, 2005) formed the general backdrop to the VEGPSP, the actual values chosen and the way they were interpreted and applied within their own context, along with curriculum choices regarding content and pedagogical processes, were entirely left to clusters and schools to fashion according to their particular needs and circumstances, with some choosing to adapt existing approaches or curricula, while others developed new approaches. Thus, a variety of strategies was employed including: philosophy in the classroom; civics learning; service learning; focus on the development of social capacities; student action teams; mentoring programs; restorative practices; and, the care of special places. 
Observations of the implementation of values education in diverse settings described in the VEGPSP Stage 1 Final Report, along with the case studies provided in Lovat \& Toomey (2007), emphasise that the very hallmarks of quality teaching (intellectual depth, communicative competence, empathic character, reflection, selfmanagement and self-knowing (Lovat,2005)) are to be intentionally and creatively implemented in good practice values education. Furthermore, effective values education cannot be left to chance; it requires vision, planning, initiative, communication, cooperation, modelling, openness, deep reflection, preparedness to be vulnerable and consider alternative points of view, and exemplary leadership that is both visionary and patient. It is a clear and overwhelming implication that effective values education depends upon the creation and maintenance of a positive, supportive web of interactions between all participants in a school community, including parents and the wider community. Values education is not a detached enterprise taking place in a social vacuum, but is firmly embedded in the very nature of the community in which it takes place. Furthermore, values are inherent in any educational enterprise and are at the very core of quality teaching. Therefore, it would be a misnomer to assume that values education is an artefact exclusive to any one particular school sector or system, although there may well be differences in the values espoused and the way they are implemented and practised. The Report indicates the profound potential of values education to transform the learning environment, ethos, coherence and inclusiveness of a school and, in so doing, to stimulate student social development by strengthening relationships between students, and students and teachers. In turn, there are cascading effects on student learning and behaviour, the way teachers teach and support their colleagues, teacher self-efficacy and sense of 
fulfilment, and communicative competency and capacity to negotiate (Lovat \& Clement, 2008).

Individual case studies, described below, taken from public, religious and private school systems, point to an effective synergy between values education and quality teaching across all school sectors and systems. These studies confirm the contention of this article that, when teachers and schools engage in pedagogical practice designed to enhance competencies necessary for personal wellbeing and social cohesion, they are involved in values education connoting a pedagogical imperative that extends beyond particular personal or systemic beliefs or ideologies.

Chapman, Cahill, and Holdsworth (2007) illustrate how 'Student Action Teams' fit within the broad genre of service learning by encouraging student responsibility for their own learning and action, thereby developing maturity, confidence and resilience in participants. The hallmarks of quality teaching were enacted in this approach through: engaging intellectual depth in tasks that require critical and conceptual analysis; developing communicative competence in expressing advanced ideas to a diverse audience and self-management; inciting deep reflection in order to monitor implemented plans in order to solve mutual problems; selfmanagement in living out values in the different environments students encounter at school, at home and in the broader community; and, self-knowledge resulting from achievements, a growing sense of responsibility to share with others while at the same time increasing in maturity and self-efficacy. Thus, beneficial effects for student engagement in learning and their psycho-social wellbeing ensued from involvement with Student Action Teams as a vehicle for values education. Remarkably, it also had a reciprocal effect in that it caused teachers to reflect on their own attitudes, values and teaching practices. In order to enable students to grow in this way, teachers had to 
abdicate control over student learning, so allowing them autonomy to plan and direct their own learning:

As a teacher I have seen how students can respond given the opportunity, how students can develop real leadership skills, how students are prepared to take full responsibility when they are engaged in the work, how effective working interactively with students from other school can be, how students engage when they feel strongly about something. For me as a teacher, it was a learning experience to allow students to take full control, and for me to support only when needed. (p.40)

The Peer Support Program, documented by Hill and Vick (2007), provided an integrated approach to values education, extending beyond peer support sessions to curriculum areas and other activities of the school. It required of teachers a movement beyond the tokenism of distributing black line masters to critical reflection on how to integrate values education into other curricula and school activities with the result that both students and teachers acknowledged the impact on the quality of school life. For students, the program improved their social skills, as well as their capacity to reflect and understand the implications of attitudes. Translated into behaviour, this resulted in an observable effect on student interaction in the playground in terms of caring, cooperation and inclusiveness, and was reflected by a reduction in the severity and number of behavioural incidents reported for disciplinary action. One school principal commented:

Our Peer Support program fosters the development of effective group work skills, values mutual respect, kindness and tolerance and celebrates the "uniqueness” of each individual. Undoubtedly Peer Support ...contributes to that greatest of Edspeak clichés - a safe and supportive school environment. But in real terms its success is there to be seen each day in the play of our 
students; in imaginative narratives, in turn-taking, in the willingness of "popular” children to include socially "awkward” children in their games and at their lunch table; in the "sacrifice" of playtime by senior students as they escort younger, injured children to the office for the ubiquitous ice pack and in the shared problem-solving it takes to find a lost hat, shoe or lunchbox.

Values education located at the intersection of values across cultures for a geographically disparate group of independent schools represented a meeting place between indigenous and non-indigenous values, so offering a context wherein students could share and explore values beyond their own and different cultural perspectives. As they engaged in learning ways of how to manage, care for and respect places of special significance, they were confronted with diverse and conflicting ways in which the same 'place' can be used according to culturally driven values. Learning involved application of values in different ambits: care for the local environment; ecological sustainability; respect for and cooperation with diverse cultural traditions; and reflecting upon, sharing and negotiating values. A significant aspect of values education, as demonstrated by this case study of Netherwood, Buchanan, Palmer, Stocker, and Down (2007), is that the values taught must be accepted autonomously and independently by a community and cannot be imposed: What was particularly important was that those involved chose a generative approach to values rather than accepting that values are always inculcated into children. Through approaches such as inquiry-based learning schools enabled children to consider their own sets of values and compare these to how others sustain places that are dear to them. This meant that children were encouraged to start with an exploration of their own values, to learn how to extend their repertoire and capacity to publicly articulate their ideas. (p.107) 
The key role of the principal in initiating communicative patterns essential to the creation and maintenance of the levels of relational trust necessary for school and community cohesion fundamental to effective values education is substantiated by the observations of McMullan and Scalfino (2007). Again, this study illustrates the necessity for school communities to identify and own their values and to bring them into dialogue with the broad values from the National Framework. Through such a process, the values of the school community became instrumental in driving school and pedagogical policy and practice, where values were translated into action, with four identified key components to: improve the learning of students; foster their wellbeing; engage the community; and, apply effective pedagogies. These served to harness the energies of all members of the school community towards a unified framework of whole-school change reflecting the identified values. It is essential therefore that values education has a whole-school approach where the values are embedded in the ethos and practices of the school as well as enjoying the consensus of the various stakeholders, including school staff, students, parents and the wider community. Visionary instructional leadership is crucial to the implementation and sustenance of quality values education:

The core idea ... is that placing values at the centre of the school and subsequently striving to live these values within the school community produces children who are highly ethical and care for those in their lives, in their local community and for the global community and environment as well. ... placing values at the centre of schooling produces quality teaching which is evidenced by intellectual depth, communicative competence, and capacity for reflection, self-management and self-knowledge. (p.64)

Overall, the reported experiences of schools participating in the study indicated that an engaging approach to values education requires the imagination, 
attention and volition of both students and teachers and that this cannot be left to chance or merely assigned to the hidden curriculum. Furthermore, the VEGPSP Stage 1 Final Report (AGDEST, 2006) confirms that effective values education employs the same characteristics that research tells us are central to quality teaching, namely intellectual depth, communicative competence, empathic character, reflection, selfmanagement and self-knowing (Lovat, 2005). As teachers engaged with these aspects of quality teaching in their own personal reflection, professional development and classroom curricula, changes were noted in student attitudes, opinions and behaviours. The profound synergy between quality teaching pedagogies and those of values education created classroom environments conducive to the improvement of student learning, where students were motivated to do their best, and give others a 'fair go.' It also instilled a calmer school climate generally with several reports of schools being better places to be (AGDEST, 2006, pp. 41, 120).

The current values education debate in Australia has provided an environment where the explicit discussion of values and new ideas and visions for values education can take place. No longer is it reasonable for values education to be assigned wholly to the implicit curriculum because now it is widely recognized that all education is values-laden, and that claims of a values-neutral stance have been shown to be empty. Nor is it sustainable that values education continues to be regarded as germane to any particular educational system, whether it be in the private, religious or public domain. Mainstream educational research, especially research pertinent to the effects of quality teaching, has demonstrated that the explicit addressing of values in a programmatic way is central to the wellbeing and betterment of students. The evidence from this research, seen clearly in the testimony coming forward from the VEGPSP, shows that the positive outcomes on all aspects of student achievement 
apply equally to all schools, and so challenge all schools to engage with values as an indispensable artefact of effective learning.

\section{Conclusion}

The foregoing analysis has identified and made explicit the values dimension of quality teaching and has shown that it is anomalous to conceive of teaching as a values-neutral exercise. As a consequence, even the most excellent technical craft in pedagogy is of dubious worth if care and concern for the welfare of the student is not palpable. Indeed, the range of features essential to quality teaching would make it unlikely that a teacher who did not care profoundly for the welfare of students would engage in such pedagogy. Striving for technical excellence in order to enable student advancement and wellbeing, therefore, is of itself grounded and motivated by values. So then, values education would seem to present as a necessary attachment, if not being an indispensable component, to any quality teaching regime. In turn, effective values education relies on the implementation of a quality teaching regime because effective education in whichever domain is empowered by intellectual depth, communicative competence, empathic character and the capacity for self reflection, all of which are essential ingredients in both quality teaching and values education. Effective values education demands full engagement of the intellect, of one's affective capacities and of high levels of self-reflectivity if it is to have the potency to challenge students to engage in their own values formation (Lovat, 2007a, 2007b).

This analysis of the reciprocal interaction of quality teaching and values education has been augmented by data from the Australian Government's Values Education Good Practice Schools Project, demonstrating that effective values education occurs in schools across public, private and religious systems. The commonality across the variety of methodologies employed is the quality of the 
pedagogy in engaging both teachers and students in 'intellectual depth', ‘communicative competence', ‘empathic character' and 'reflective activity’. Furthermore, it demonstrates that values education is not the exclusive province of any particular educational sector, whether public, private or religious. Schools that proactively engage the nexus between values education and quality teaching will be at the forefront of impelling student development and achievement of the most comprehensive and superlative kind. Thus, values education has an imperative that extends beyond personal or systemic beliefs or ideologies and is engaged by pedagogical practices designed to enhance competencies necessary for personal wellbeing, social cohesion, and academic advancement. In a word, values education is a pedagogical imperative.

\section{References}

Australian Government Department of Education, Science and Training (AGDEST). (2005) National framework for values education in Australian schools, (Canberra, Department of Education, Science and Training). Available online at:

http://www.valueseducation.edu.au/verve/_resources/Framework_PDF_versio n_for_the_web_left_column_file_link.pdf.

Australian Government Department of Education, Science and Training (AGDEST). (2006) Implementing the National Framework for Values Education in Australian Schools: Report of the Values Education Good Practice Schools Project - Stage 1: Final report, September 2006, (Carlton South, Vic., Curriculum Corporation). Available online at: http://www.valueseducation.edu.au/values/default.asp?id=16381. 
Alton-Lee, A. (2003) Quality teaching for diverse students in schooling: Best evidence synthesis, (Wellington, New Zealand Ministry of Education). Available online at: http://www.educationcounts.govt.nz/publications/series/ibes/quality_teaching_ for_diverse_students_in_schooling.

Aspin, D. (2000) A clarification of some key terms in values discussions, in: M. Leicester, C. Modgil \& S. Modgil (Eds) Education, culture and values: Moral education and pluralism. (vol. IV) (London \& New York, Falmer Press), 1631.

Australian Government House of Representatives Standing Committee on Education and Training (2002) Boys: Getting it right: Report on the inquiry into the education of boys. Report for The Parliament of the Commonwealth of Australia (Canberra, A.C.T.).

Avery, P. G. (1999) Authentic assessment and instruction. Social Education, 63(6), 368-373.

Brady, L. (2005) Dimensions of teaching. Curriculum and Teaching, 20(1), 5-14.

Bruer, J. T. (1999) In Search of . . Brain-Based Education. Phi Delta Kappan, 80(9), 648.

Bryk, A. S. (1988) Musings on the moral life of schools. American Journal of Education, 96(2), 256-290.

Bryk, A. S., Lee, V. E. \& Holland, P. B. (1993) Catholic schools and the common good, (Cambridge, Mass., Harvard University Press).

Bryk, A. S. \& Schneider, B. (1996) Social trust: A moral resource for school improvement, (Chicago, Consortium on Chicago School Research.). (ERIC Document Reproduction Service ED 412630). 
Bryk, A. S. \& Schneider, B. (2002) Trust in schools: A core resource for improvement, (New York, Russell Sage Foundation).

Bryk, A. S. \& Schneider, B. (2003) Trust in Schools: A core resource for school reform. Educational Leadership, 60(6), 40.

Carbone, P. F., Jr. (1991) Perspectives on values education. Clearing House, 64(5), 290-292.

Carnegie Corporation (1996) Years of promise: A comprehensive learning strategy for America's children. The report of the Carnegie Task Force on learning in the primary grades. (Carnegie Corporation of New York, New York). (ERIC Document Reproduction Service No. ED397995).

Carr, D. (2005) Personal and interpersonal relationships in education and teaching: A virtue ethical perspective. British Journal of Educational Studies, 53(3), 255271.

Carr, D. (2006) Professional and personal values and virtues in teaching. Oxford Review of Education, 32(2), 171-183.

Cawsey, C. (2002) Naming, measuring and modelling the values of public education, in: S. Pascoe (Ed.) Values in education: College year book 2002. Deakin West, A.C.T., Australian College of Educators), 71-84.

Central Advisory Council for Education (UK). (1967) Children and their Primary Schools: A report ('The Plowden Report'), (London, London: HMSO). Available online at: http://www.dg.dial.pipex.com/documents/plowden.shtml.

Chapman, J. D., Cahill, S. \& Holdsworth, R. (2007) Student action teams values education and quality teaching and learning - Case study from Manning Cluster, Victoria, in: T. J. Lovat \& R. Toomey (Eds) Values education and 
quality teaching: the double helix effect. (Sydney, David Barlow Publishing), 28-48.

Clement, N. D. (2007) Perspectives from research and practice in values education, in: T. J. Lovat \& R. Toomey (Eds) Values education and quality teaching: the double helix effect. (Sydney, David Barlow Publishing), 13-27.

Coleman, J. S., Campbell, E., Hobson, E., McPartland, J., Mood, A., Weinfied, F. \& York (1966) Equality of educational opportunity, (Washington, U.S. Dept. of Health, Education, and Welfare, Office of Education).

Coleman, J. S., Hoffer, T. \& Kilgore, S. (1982) Cognitive Outcomes in Public and Private Schools. Sociology of Education, 55(2/3), 65-76.

Cunningham, C. A. (2005) A certain reasoned art: The rise and fall of character education in America, in: D. K. Lapsley \& F. C. Power (Eds) Character psychology and character education. (Notre Dame, IN, University of Notre Dame Press), 166-200.

Darling-Hammond, L. (1996) What matters most: A competent teacher for every child. Phi Delta Kappan, 78(3), 193-200.

Darling-Hammond, L. (1998) Teachers and teaching: Testing policy hypotheses from a National Commission report. Educational Researcher, 27(1), 5-15.

Darling-Hammond, L. (2000) Teacher Quality and Student Achievement: A Review of State Policy Evidence. Education Policy Analysis Archives, 8(1). Available online at: http://epaa.asu.edu/epaa/v8n1/.

Darling-Hammond, L. \& Youngs, P. (2002) Defining "Highly Qualified Teachers": What does "Scientifically-Based Research" actually tell us? Educational Researcher, 31(9), 13-25. 
Deakin Crick, R. (2007) Learning how to learn: the dynamic assessment of learning power. Curriculum Journal, 18(2), 135 - 153.

Deakin Crick, R., Broadfoot, P. \& Claxton, G. (2004) Developing an Effective Lifelong Learning Inventory: the ELLI Project. Assessment in Education: Principles, Policy \& Practice, 11(3), 247 - 272.

Deakin Crick, R., McCombs, B., Haddon, A., Broadfoot, P. \& Tew, M. (2007) The ecology of learning: factors contributing to learner-centred classroom cultures. Research Papers in Education, 22(3), 267 - 307.

Elliott, R. \& Hatton, E. (1994) Neutrality and the value ladenness of teaching, in: E. Hatton (Ed.) Understanding teaching: Curriculum and the social context of schooling. (Sydney, Harcourt Brace), 49-60.

Fallon, D. (2003) Case study of a paradigm shift: The value of focusing on instruction. Available online at: http://www.ecs.org/clearinghouse/49/00/4900.htm (accessed 14 December 2005).

Farrer, F. (2000) A quiet revolution: Encouraging positive values in our children, (London, Random House).

Halliday, J. (1998) Technicism, reflective practice and authenticity in teacher education. Teaching and Teacher Education, 14(6), 597-605.

Halstead, J. M. (1996) Values and values education in schools, in: J. M. Halstead \& M. J. Taylor (Eds) Values in education and education in values. London, Falmer Press), 3-14.

Hansen, D. T. (1998) The moral is in the practice. Teaching and Teacher Education, 14(6), 643-655. 
Hattie, J. (2004) It's official: Teachers make a difference. Educare News, 144, 24, 26, 28-31.

Hawkes, N. (2005) Does teaching values improve the quality of education in primary schools? - A study about the impact of introducing values education in primary school. D Phil diss., Oxford.

Hawkes, N. (2007) Values and quality teaching at West Kidlington Primary School, in: T. J. Lovat \& R. Toomey (Eds) Values education and quality teaching: the double helix effect. (Sydney, David Barlow Publishing), 115-133.

Hill, A. \& Vick, M. (2007) Moving values beyond the half hour: Peer leadership and school vision - A case study of the Townsville Cluster, Queensland, in: T. J. Lovat \& R. Toomey (Eds) Values education and quality teaching: the double helix effect. (Sydney, David Barlow Publishing), 69-90.

Hill, P. T., Foster, G. E. \& Gendler, T. (1990) High schools with character, (Santa Monica, CA, Rand).

Hooper, C. (2003) Values education study: Literature Review, in: V. Zbar, D. Brown \& B. Bereznicki (Eds) Values education study - final report, 2003. (Melbourne, Curriculum Corporation), 168-212.

Jencks, C. (1985) How Much Do High School Students Learn? Sociology of Education, 58(2), 128-135.

Jencks, C. et al (1972) Inequality: A reassessment of the effect of family and schooling in America, (New York, Basic Books).

Jordan, H. R., Mendro, R. L. \& Weerasinghe, D. (1997) Teacher effects on longitudinal student achievement, paper presented at the 1997 CREATE annual meeting, City, July, 1997. 
King, M. B., Schroeder, J. \& Chawszczewski, D. (2001) Authentic assessment and student performance in Inclusive schools, Brief \#5. Report for Research Institute on Secondary Education Reform (RISER) for Youth with Disabilities (Madison, WI).

Ladwig, J. G. \& King, M. B. (2003) Quality teaching in NSW public schools: An annotated bibliography, (Sydney, State of New South Wales, Department of Education and Training).

Lee, V. E. \& Bryk, A. S. (1988) Curriculum Tracking as Mediating the Social Distribution of High School Achievement. Sociology of Education, 61(2), 7894.

Lee, V. E. \& Bryk, A. S. (1989) A Multilevel Model of the Social Distribution of High School Achievement. Sociology of Education, 62(3), 172-192.

Lee, V. E. \& Smith, J. B. (1999) Social support and achievement for young adolescents in Chicago: The role of school academic press. American Educational Research Journal, 36(4), 907-945.

Leming, J. S. (1993) In search of effective character education. Educational Leadership, 51(3), 63-71.

Lickona, T. (1993) The return of character education. Educational Leadership, 51(3), $6-10$.

Louden, W., Rohl, M., Barrat-Pugh, C., Brown, C., Cairney, T., Elderfield, J., House, H., Meiers, M., Rivaland, J. \& Rowe, K. J. (2005) In teachers' hands: Effective literacy teaching practices in the early years of schooling, (Canberra, ACT, Australian Government Department of Education, Science and Training). Available online at: http://inteachershands.education.ecu.edu.au/). 
Lovat, T. J. (2005) What is Values Education all about? Available online at: http://www.valueseducation.edu.au/verve/_resources/Terry_Lovat_VE_Newsl etter.pdf.

Lovat, T. J. (2007a) Values education and quality teaching: two sides or the learning coin, in: T. J. Lovat \& R. Toomey (Eds) Values education and quality teaching: the double helix effect. (Sydney, David Barlow Publishing), 1-12.

Lovat, T. J. (2007b) Values Education: The missing link in quality teaching and effective learning, in: D. N. Aspin \& J. D. Chapman (Eds) Values education and lifelong learning: Principles, policies, programmes. (Dordrecht, The Netherlands, Springer Verlag), 199-210.

Lovat, T. J. \& Clement, N. D. (2008) Quality teaching and values education: Coalescing for effective learning. Journal of Moral Education, 37(1), 1-16.

Lovat, T. J. \& Schofield, N. (2004) Values education for all schools and systems: A justification and experimental update. New Horizons in Education, 111, 4-13.

Lovat, T. J. \& Toomey, R. (Eds.) (2007) Values education and quality teaching: the double helix effect, (Sydney, David Barlow Publishing).

McLaughlin, T. H. (2005) The educative importance of ethos. British Journal of Educational Studies, 53(3), 306-325.

McMullan, C. \& Scalfino, L. (2007) Placing values at the core of school policy and classroom practice - A case study of Modbury School, South Australia, in: T. J. Lovat \& R. Toomey (Eds) Values education and quality teaching: the double helix effect. (Sydney, David Barlow Publishing), 49-68.

Netherwood, K., Buchanan, J., Palmer, D., Stocker, L. \& Down, B. (2007) Valuing diversity in children's voice: A case study of children, stewardship and mapping the care of special places in the Western Australia Cluster, in: T. J. 
Lovat \& R. Toomey (Eds) Values education and quality teaching: the double helix effect. (Sydney, David Barlow Publishing), 91-114.

Newmann, F. M. (1991) Linking restructuring to authentic student achievement. Phi Delta Kappan, 72(6), 458-461.

Newmann, F. M. \& Associates (1996) Authentic achievement: Restructuring schools for intellectual quality, (First edn) (San Francisco, Jossey-Bass Publishers).

Newmann, F. M., Marks, H. M. \& Gamoran, A. (1996) Authentic pedagogy and student performance. American Journal of Education, 104(4), 280-312.

Newmann, F. M. \& Wehlage, G. G. (1995) Successful school restructuring: A report to the public and educators: Executive summary. Available online at: http://www.wcer.wisc.edu/archive/cors/Successful_School_Restruct.html.

Noddings, N. (1997) Character education and community, in: A. Molnar (Ed.) The construction of children's character. Chicago \& Great Britain, National Society for the Study of Education), 1-16.

Prosser, G. \& Deakin, R. (1997) An exploration of spiritual, moral, social and cultural development of children in school: the whole child and school ethos a qualitative study. Available online at: http://www.becal.net/toolkit/acorneres/acorneres.html (accessed 15 March 2006).

Reynolds, D. (1992) School effectiveness and School Improvement: An updated review of the British literature, in: D. Reynolds \& P. Cuttance (Eds) School effectiveness: Research, policy and practice. (London \& New York, Cassell), $1-24$.

Reynolds, D., Hargreaves, A. \& Blackstone, T. (1980) Fifteen thousand hours: Secondary schools and their effects on children (Review Symposium of Rutter 
et al. Fifteen thousand hours). British Journal of Sociology of Education, 1(2), 207-219.

Rowe, K. J. (2004) In good hands? The importance of teacher quality. Educare News, 149, 4-14.

Rutter, M., Maughan, M., Mortimore, P., Ousten, J. \& Smith, A. (1979) Fifteen thousand hours: Secondary schools and their effects on children, (London, Open Books).

Sanders, W. L. \& Rivers, J. C. (1996) Cumulative and residual effects of teachers on future student academic achievement. Report for University of Tennessee Value-Added Research and Assessment Centre (Knoxville, Tennessee).

Scanlon, L. (2004) 'She just blends and just comes down to our level and communicates with us like we're people': Students' perceptions of quality teaching and teaching standards. Change: Transformations in Education, 7(1), 93-108.

Scheerens, J. \& Bosker, R. J. (1997) The foundations of educational effectiveness, (Oxford, New York NY, Pergamon).

Scheerens, J., Vermeulen, C. J. A. J. \& Pelgrum, W. J. (1989) Generalizability of instructional and school effectiveness indicators across nations. International Journal of Educational Research, 13(7), 789-799.

Slade, M. (2001) Listening to boys. The Boys in School Bulletin, 4(1), 10-18. Available online at: http://www.newcastle.edu.au/centre/fac/publicationsresources/boysinschoolsbulletin.html.

Van Petegem, K., Aelterman, A., Van Keer, H. \& Rosseel, Y. (2008) The influence of student characteristics and interpersonal teacher behaviour in the classroom on student’s wellbeing. Social Indicators Research, 85(2), 279-291. 
Veugelers, W. (2000) Different ways of teaching values. Educational Review, 52(1), 37-46.

Veugelers, W. \& Vedder, P. (2003) Values in teaching. Teachers and Teaching: Theory and Practice, 9(4), 377-389.

Wang, M., Haertel, G. D. \& Walberg, H. J. (1993) Toward a knowledge base for school learning. Review of Educational Research, 63(3), 249-294.

Willms, J. D. (2000) Monitoring school performance for standards-based reform. Evaluation and Research in Education, 14(3\&4), 237-253. 